11 Correa P, Haenszel W, Cuello C, Archer M, Tannenbaum S. A model for gastric cancer epidemiology. Lancet 1975;ii:58-60.

12 Correa P. The gastric precancerous process. Cancer Surveys 1983;2:437-50.

13 Hartman PE. Nitrate/nitrite ingestion and gastric cancer mortality. Environ Mutagen 1983;5:111-21.

14 National Academy of Sciences. The health effects of nitrite, nitrate, and $\mathrm{N}$-nitroso compounds. Washington DC: National Academy Press, 1981.

15 Department of the Environment. Nitrate in water. London: HMSO, 1986. (Pollution Paper No 26.)

16 Dudley N. Nitrates in food and water. London: London Food Commission, 1986.

17 Cuello C, Correa P, Haenszel W, et al. Gastric cancer in Columbia. 1. Cancer risk and suspect environmental agents. FNCI 1976;57:1015-20.

8 Armijo R, Coulson AH. Epidemiology of stomach cancer in Chile-the role of nitrogen fertilizers. Int $\mathcal{F}$ Epidemiol 1975;4:301-9.

19 Jensen OM. Nitrate in drinking water and cancer in Northern Jutland, Denmark, with special reference to stomach cancer. Ecotoxicol Environ Safety 1982;6:258-67.

20 Forman D, Al-Dabbagh SA, Doll R. Nitrates, nitrites and gastric cancer in Great Britain. Nature 1985;313:620-5.

21 Kamiyama S, Ohshima $\mathrm{H}$, Shimada $\mathrm{A}$, et al. Urinary excretion of $\mathrm{N}$-nitrosoamino acids and nitrate by inhabitants in high and low risk areas for stomach cancer in Northern Japan. In: O'Neill I, Bartsch H, Schulte-Hermann R, eds. Relevance of $N$-nitroso compounds to human cancer: exposure and mechanisms. Lyons: IARC, 1987.

22 Fontham E, Zavala D, Correa P, et al. Diet and chronic atrophic gastritis: a case-control study. FNCI 1986;76:621-7.

23 Beresford SA. Is nitrate in the drinking water associated with the risk of stomach cancer in the urban UK? Int $\mathcal{F}$ Epidemiol 1985;14:57-63.

24 Vincent P, DuBois G, LeClerc H. Nitrates dans l'eau de boisson et mortalité par cancer. Rev Epidemiol Sante Publique 1983;31:199-207.

25 Al-Dabbagh S, Forman D, Bryson D, Stratton I, Doll R. Mortality of nitrate fertilizer workers. Br f Ind Med 1986;43:507-15.

26 Mirvish SS, Wallcave L, Eagen M, Shubik P. Ascorbate-nitrite reaction: a possible means of blocking the formation of carcinogenic $N$-nitroso compounds. Science 1972;177:65-8.

27 Wakabayshi K, Ochiai M, Saito H, et al. Presence of 1-methyl-1,2,3,4-tetrahydro-beta-carboline3-carboxylic acid, a precursor of a mutagenic nitroso compound, in soy sauce. Proc Natl Acad Sci USA 1983;80:2912-16.

28 Weisburger $\mathrm{JH}$, Horn CL. Human and laboratory studies on the causes of gastrointestinal cancer Scand $\mathcal{F}$ Gastroenterol 1984;104:15-26.

9 Yang D, Tannenbaum SR, Buchi G, Lee GCM. 4-chloro-6-methoxinodole is the precursor of potent mutagen that forms during nitrosation of the fava bean. Carcinogenesis 1984:5:1219-24. 30 Correa P, Cuello C, Fajardo LF, Haenszel W, Bolanos O, de Ramirez B. Diet and gastric cancer: nutrition survey in a high-risk area. $7 N C I$ 1983;70:673-8.

\section{Juvenile intestinal polyps-are they always benign?}

Standard paediatric teaching is that juvenile intestinal polyps, particularly if solitary, are always benign with no risk of adenomatous or carcinomatous change. ${ }^{1}$ Recent evidence suggests, however, that this may not always be true and polyps will sometimes need to be removed.

Although these polyps can occur at any age, they are commonest in prepubertal children, particularly those under 6 . They may occur in as many as $1 \%$ of children and usually cause painless rectal bleeding. They may, however, prolapse or present as vague abdominal pain and cramp. Typically $1-2 \mathrm{~cm}$ in diameter, they either have a smooth oedematous surface or are granulomatous and ulcerated. The characteristic histological features are chronic inflammatory changes with dilated and hyperplastic glands.

The origin of the polyps remains obscure, and they may simply arise as folds of mucosa that get drawn out with the formation of a pedicle. They might, however, be hamartomatous, a view supported by the fact that they are often familial and sometimes occur throughout the gut as multiple juvenile polyposis. ${ }^{2}$ Until the advent of routine colonoscopy and double contrast barium enemas the lesions were thought to be solitary in most cases and two thirds of them were said to be found within $10 \mathrm{~cm}$ of the anal verge. ${ }^{3}$

The possibility of adenomatous or carcinomatous change has occasionally been considered. Mazer $e t a l$ in a series of 258 patients of all ages with juvenile polyps identified 10 patients under 20 with solitary adenomas-and two of these were under $5 .^{3}$ They concluded that about $5 \%$ of solitary polyps were actually adenomatous and left open the question of whether in children adenomas may become malignant. There have been sporadic case reports of frank malignant change. In 1954 Schilla reported a case of a 2 year old Mexican child with carcinomatous degeneration in a solitary polyp, ${ }^{4}$ and in 1978 Liu Tung-hua described a 16 year old boy with carcinoma cells in the middle of a large, pedunculated, classical juvenile polyp. ${ }^{\mathrm{s}}$

The most recent reviews have further emphasised the view that juvenile polyps should not be regarded as invariably benign. Mestre described 76 children with polyps seen over 10 years and with improved investigatory techniques showed that over half had multiple polyps that occurred in almost equal numbers in the ascending, transverse, and descending colon. ${ }^{6}$ With increasing numbers of polyps there was, he suggested, an increasing risk of adenomatous change, and he therefore proposed that any child suspected of having a juvenile polyp should undergo full colonoscopy and have all polyps removed. This view was supported by a leading article in the same journal that advocated removing any polyps found in a child over $8 .{ }^{7}$ In a younger child a single polyp may be observed for a year-because many of them will autoamputate and be passed-but all multiple polyps should be removed at the time of diagnosis.

We can no longer regard all juvenile polyps as benign and must recognise that solitary lesions are less common than multiple lesions. Adenomatous changes are a cause for concern, but frank malignant change is very rare. Any child with unexplained gastrointestinal bleeding should be considered for examination by sigmoidoscopy and double contrast barium enema with the option of a full colonoscopy if the facilities exist locally. ${ }^{8}$ Polypectomy is usually straightforward and may be carried out during endoscopic examination. Recurrence has not been reported, and if histological examination confirms the benign nature of the lesions long term follow up is probably not needed.

C J Rolles

Consultant Paediatrician,

Southampton General Hospital,

Southampton SO9 4XY

1 Anderson CM, Burke V. Paediatric gastroenterology. Oxford: Blackwell Scientific Publications, $1975 ; 482$.

2 Morson BC. Some peculiarities in the histology of intestinal polyps. Dis Colon Rectum 1962;154: 829-32.

3 Mazier WP, MacKeigan JM, Billingham RP, et al. Juvenile polyps of the colon and rectum. Surg Gynecol Obstet 1982;154:829-32.

4 Schilla FW. Carcinoma in a rectal polyp. Am $\mathcal{f}$ Surg 1954;4:434-9.

5 Liu TH, Chen MC, Tseng HC, et al. Malignant change of juvenile polyp of colon. Chin Med $\mathcal{J}$ 1978;4:434-9.

6 Mestre J. The changing pattern of juvenile polyps. Am 7 Gastroenterol 1986;81:312-4.

7 Gryboski J. All juvenile polyps are not benign. Am $\mathcal{J}$ Gastroenterol 1986;81:397.

8 Douglas JR, Campbell CA, Salisbury DM, Walker-Smith JA, Williams CB. Colonoscopic polypectomy in children. $\mathrm{Br} M e d$ F 1980;281:1386-7.

\section{Funding the universities}

The concept of university autonomy within a system of state funding poses a problem. The committee appointed by Sir Keith Joseph under Lord Croham's chairmanship to review the University Grants Committee clearly recognised the dilemma, as did the Robbins committee 25 years earlier, but its report does not suggest that it saw irreconcilable difficulties. ${ }^{1}$

There is no doubt that the review was needed. Times have changed since the UGC was established in 1919. With the growth of the universities the work of the UGC expanded steadily, as did the range of its activities and responsibilities. During the period of expansion after the 
second world war the UGC of necessity increasingly participated in central planning and the expenditure of university resources. Nevertheless, its different relationships with government and with individual universities remained compatible and were based more on convention than on legal definition. It has been the period of contraction of the past few years that has glaringly revealed the weaknesses of constitutional imprecision. Hard times have uncovered other weaknesses and have imposed burdens on the committee beyond its resources. Its terms of reference are not as explicit as they might be, and the work of the subcommittees does not always harmonise with that of the main committee; universities are frequently confused by the planning methods of both. The Public Accounts Committee has expressed dissatisfaction with the present basis of accountability for the expenditure of public monies by universities.

Some of the criticisms levelled at the UGC are justified but others are not or are beyond its power to control. Academics complain that the UGC fails to represent their interests, but this is not its job. It is an instrument of government rather than a champion of the university cause. There are many adverse operating conditions that are not of its choosing. Apart from the general reduction in funding there are political pressures that are inimical to the higher education ethos. The drive towards applied research, the increasing dependence on money from the private sector, and the contraction of research budgets are but a few examples. The universities do not project a good public image, and their potential for contributing to the wealth and wellbeing of the nation is not appreciated. As a nation we undervalue our educational system.

So Croham was confronted with a formidable task and his committee tackled it boldly. His recommendations include a change of name, to University Grants Council, and of legal status by formal incorporation by statute or royal charter. He recommends that the council should have no more than 15 members without a majority of academics and with a lay chairman. There should be a director general drawn from the academic world with substantial executive power and particular responsibility for translating the principles agreed by the council into recommended allocations to the universities. The secretariat should be strengthened with the establishment of a management information service. The present subject committee structure would be substantially trimmed. A system of triennial funding is recommendedperhaps optimistically - with a clear cycle of consultation on resource allocation with the Department of Education and Science.

At first sight the individual recommendations may not seem too radical a departure from the existing pattern, but put together they add up to a formidable package. Authority would be strengthened and the restyled council could readily become a more political instrument than its predecessor. Apart from the structural changes that are recommended there are clear indications in the text of a determination to push ahead with current initiatives: the development of performance indicators; selectivity in funding; greater accountability; and more emphasis on earmarking.

What of the implications for medicine of Lord Croham's recommendations? Readers of the $B M F$ do not need to be reminded of the mounting concern about current threats to academic medicine. A succession of leading articles, letters, and reports on conferences have spelt out in plain terms the effects on tomorrow's health services of today's NHS and UGC funding policies. Many voices have been raised in protest, and even the General Medical Council, wary of political involvement and mindful of its responsibility for standards and not resources, has felt obliged to warn the secretaries of state of both the health and the education departments of the consequences of a decline in medical education. A well informed debate in the House of Lords in November spelt out in detail the implications of current policies, yet sadly the government response was one of complacent reassurance that was as predictable as it was unconvincing. ${ }^{2}$ The list of those proffering advice to the Croham committee shows that medicine was well represented, and the six page section of the report devoted to medical education makes it clear that the committee listened. Most of the detailed recommendations contained in the report were described in last week's $B M \mathcal{F}$ ( $p$ 514). What is particularly encouraging is that the necessity for increased consultation and collaboration between the Department of Education and Science and the health departments is clearly understood and the report is insistent that mechanisms for joint policy development must be tackled urgently. There is a recommendation that academic and financial plans for medical and dental schools should be subject to specific consultation with relevant health authorities before submission to the new UGC, which will be required to have in its membership a person with first hand experience of medical matters. There is no other specific prescription as to membership.

While welcoming that part of the Croham report that relates to medicine, many will be alarmed by the overall burden of its message. Universities are inclined to reject the idea that the instruments of commercial management may have relevance to their own operation. Certainly there are differences, but even universities deal with commodities that are assessable in terms of their quality, their marketability, and their value for money. Whether or not the Croham recommendations are adopted there can be no doubt that the style of management in universities will change; performance will be measured and accountability demanded. The committee was right to take as its starting point the political and financial realities of the day rather than an idealised construct based on the universities' view of themselves and their aspirations of yesterday. If academic life is to change, and change it will, better that it should do so within a framework of explicit planning methods and information systems and in collaboration with an administrative authority whose role is unambiguous.

Professor of Clinical Neurology and

Dean of Medicine,

The Medical School,

University of Newcastle upon Tyne,

Newcastle upon Tyne NE2 4HH

1 Anonymous. Review of the University Grants Committee. London: HMSO, 1987. (Croham report.) 2 Prys-Davies Lord. Academic medicine and the NHS. House of Lords Official Report (Hansard) 1986 November 26:482 (cols 590-621). (No 7.) 